\title{
Laparoscopic resection for colorectal diseases: short-term outcomes of a single center
}

\author{
Wafi Attaallah, Hayyam Babayev, Samet Yardımcı, Asım Cingi, Mustafa Ümit Uğurlu, Ömer Günal
}

\begin{tabular}{|c|c|}
\hline \multirow[t]{5}{*}{ ABSTRACT } & $\begin{array}{l}\text { Objective: Even though, laparoscopy is not accepted as the current gold standard in colorectal surgery, it can be per- } \\
\text { formed as safely as open surgery. It is also widely accepted that the technique has many advantages. In this study, } \\
\text { we evaluated the results of } 33 \text { patients with laparoscopic colorectal resection. }\end{array}$ \\
\hline & $\begin{array}{l}\text { Material and Methods: Thirty-three patients who underwent laparoscopic colon surgery between January } 2013 \text { and } \\
\text { September } 2014 \text { in the General Surgery Clinic at Marmara University Hospital were included in the study. Patients } \\
\text { were evaluated in terms of their demographic and tumor histopathologic characteristics, type of surgery and early } \\
\text { postoperative complications. }\end{array}$ \\
\hline & $\begin{array}{l}\text { Results: Laparoscopic colorectal resection was performed for } 33 \text { patients who had malignant or benign lesions. The } \\
\text { median age was } 60 \text { (35-70), and } 18(55 \%) \text { were male patients. The majority of the patients }(90 \%) \text { were diagnosed with } \\
\text { colorectal adenocarcinoma. Half of the patients were T3 and } 67 \% \text { had N0 stage. The median number of retrieved } \\
\text { lymph nodes was } 17 \text { (4-28). Negative surgical margins were obtained in all patients. The postoperative hospital stay } \\
\text { was } 5 \text { (4-16) days. Postoperative early complications were observed in only } 5 \text { patients. The majority of complications } \\
\text { were treated without the need for surgery. No mortality was recorded in this series of patients. }\end{array}$ \\
\hline & $\begin{array}{l}\text { Conclusion: This study showed that laparoscopic colorectal surgery could be performed safely based on its low } \\
\text { complication rate, short length of hospital stay, providing sufficient surgical resection and lymph node dissection. }\end{array}$ \\
\hline & Keywords: Laparoscopy, colorectal surgery, colon resection \\
\hline
\end{tabular}

Department of General Surgery, Marmara University Faculty of Medicine, İstanbul, Turkey

Address for Correspondence Wafi Attaallah e-mail: drwafi2003@yahoo.com

Received: 25.02 .2015

Accepted: 08.04.2015

Available Online Date: 06.04.2016

(c) Copyright 2016

by Turkish Surgical Association

Available online at

www.ulusalcerrahidergisi.org

\section{INTRODUCTION}

Laparoscopic colorectal surgery provides less postoperative pain, better cosmesis, shorter hospital stay and earlier patient mobilization (1, 2). Jacobs et al. (3) performed the first laparoscopic colon resection in 1991 (3). However, it took time to be adopted due to its technical difficulties, lack of clinical evidence, the learning curve and fear of tumor seeding $(4,5)$. The recently published case series proved that there was no significant difference between open and laparoscopic colorectal surgery in terms of tumor recurrence, distant metastasis rates and disease free survival (6-8). Although laparoscopy is still not the gold standard in colorectal surgery, its advantages in experienced hands are acknowledged (9). In our study, we presented 33 cases who underwent laparoscopic colorectal resection for benign or malignant diseases.

\section{MATERIAL AND METHODS}

Thirty-three patients underwent laparoscopic colorectal surgery between January 2013-September 2014. An ethics committee approval was obtained from Marmara University. Our prospective database consisted of information on patient demographics, pathology reports (TNM stage, number of dissected lymph nodes), operation type, complications and length of hospital stay.

All the patients were evaluated for presence of locoregional disease and distant metastasis with colonoscopy, computed thoracic and abdominal tomography and/or pelvic magnetic resonance imaging. Patients were informed on laparoscopic surgery and their consents were obtained. Locally advanced rectal cancers were treated with neoadjuvant chemotherapy and radiation therapy. Preoperative bowel preparation was achieved by sodium phosphate containing purgatives, and the antibiotic prophylaxis consisted of $2 \mathrm{gr}$ Cefazolin and $500 \mathrm{mg}$ Metronidazole. A second antibiotic dose was administered in operations lasting longer than 4 hours. Low molecular weight heparins were applied for thrombo-emboli prophylaxis with a dose adjusted for body weight 12 hours before the operation.

Under general anesthesia, a $1 \mathrm{~cm}$ supra-umbilical skin incision was done followed by Veress needle insertion for carbon dioxide insufflation up to 10-12 millimeter mercury ( $\mathrm{mmHg}$ ). Mesocolic excision was performed for colon tumors and total mesorectal excision was performed for rectal cancers. To avoid seeding and surgical site infection, a wound protector was used in all operations (Alexis ${ }^{\circledast} \mathrm{O}^{\mathrm{TM}}$ Retrac- 
tor. Applied Medical Resources Corporation, Rancho Santa Margarita, CA; USA). Negative pressure drains were placed to the operative field after completion of surgical procedure. Postoperatively, peroral feeding was started either when the bowel movements were observed or with patient declaration of flatus. Early and late complications were recorded by weekly patient visits or by using radiologic assessment tools up to 1 month.

The surgical specimens were evaluated for tumor type, grade, lymph node number and metastasis, presence of perineural invasion and surgical margins. Staging was done according to the American Joint Committee on Cancer (AJCC) 2010 system.

\section{Statistical Analysis}

Data were analyzed using Statistical Package for Social Sciences for Windows version 17.0 (SPSS Inc; Chicago, IL, USA). Parametric data was given as mean \pm standard deviation, and nonparametric data as median with range (minimum-maximum).

\section{RESULTS}

Three hundred and sixty-six patients underwent colorectal surgery for either benign or malignant etiologies between January 2013-September 201336 (10\%) of whom were operated laparoscopically. In the laparoscopy group, three surgeries were converted to open procedures; hence, 33 patients were included in the final analysis. The mean patient age was 60 (35-70) years, and 56\% (n: 18) were male. Ninety percent of patients were diagnosed with colorectal adenocarcinoma. Anorectal cancer constituted $45 \%$ (n: 15 ), and $43 \%$ of them were treated with neoadjuvant chemotherapy and radiotherapy (Table 1). Patients with anorectal cancer were treated with abdominoperineal resection ( $\mathrm{n}$ : 9) or low anterior resection (n: 6); loop ileostomy was performed in 5 patients in addition to coloanal anastomosis. All rectal cancers were operated by using the total mesorectal excision technique. Patients who were operated laparoscopically for benign diseases included one patient with Crohn's disease, one with familial adenomatous polyposis and one with villous adenoma (Table 2).

Co-morbid diseases consisted of diabetes mellitus (18\%), hypertension (6\%), chronic obstructive pulmonary disease (3\%), and coronary artery disease (3\%).

Histopathologic results are shown in Table 3. Two patients had in situ carcinoma, $1 \mathrm{~T} 1,3 \mathrm{~T} 2$, and 14 had T3 cancers. The median number of dissected lymph nodes was 17 (range: 4-28). The patient with 4 dissected lymph nodes in the final specimen was diagnosed as carcinoma in situ. $67 \%$ of the patients were lymphatic metastasis free, $23 \%$ (n: 7) had N1, and $10 \%$ (n: 3 ) had N2 disease. Surgical margins were negative in all patients. The median length of hospital stay was 5 (4-16) days.

$15.2 \%$ of the patients had early postoperative complications. Superficial surgical site infection was observed in 1 patient who had right hemicolectomy and in 1 patient who had anterior resection. They both were treated with drainage and antibiotics. One patient with abdominoperineal resection had bowel obstruction, and he was treated by nasogastric decompression alone without requiring an additional operation.
Table 1. Demographics and preoperative characteristics of patients $(n=33)$

\begin{tabular}{|l|l|}
\hline Age [Median (Min-Max)] & $60(30-75)$ \\
\hline Gender & $18(55 \%)$ \\
\hline Male & $15(45 \%)$ \\
\hline Female & \\
\hline Preoperative diagnosis & $30(91 \%)$ \\
\hline Adenocarcinoma & $1(3 \%)$ \\
\hline Attenuated FAP & $1(3 \%)$ \\
\hline Villous adenoma & $1(3 \%)$ \\
\hline Crohn's disease & \\
\hline Localization of the lesion & $5(15 \%)$ \\
\hline Cecum & $5(15 \%)$ \\
\hline Ascending colon & $2(6 \%)$ \\
\hline Descending colon & $6(18 \%)$ \\
\hline Sigmoid colon & $12(36 \%)$ \\
\hline Rectum & $3(9 \%)$ \\
\hline Anal canal & $2(6 \%)$ \\
\hline Liver metastasis & $13(43 \%)$ \\
\hline Neoadjuvant radiotherapy & \\
\hline
\end{tabular}

FAP: familial adenomatous polyposis

Table 2. Types of laparoscopic procedures performed

\begin{tabular}{|l|l|}
\hline Laparoscopic procedure & Number of patients (\%) \\
\hline Abdominoperineal resection & $8(24.2)$ \\
\hline $\begin{array}{l}\text { Abdominoperineal resection } \\
\text { +liver metastasectomy }\end{array}$ & $1(3)$ \\
\hline Ileocecal resection & $1(3)$ \\
\hline Sigmoid colon + small bowel resection & $1(3)$ \\
\hline Low anterior resection & $4(12,1)$ \\
\hline Low anterior resection + loop ileostomy & $5(16,2)$ \\
\hline Right hemicolectomy & $9(27.3)$ \\
\hline Sigmoid resection & $3(9,1)$ \\
\hline Left hemicolectomy & $1(3)$ \\
\hline Total & $33(100)$ \\
\hline
\end{tabular}

re-operated for long lasting bowel obstruction. An intraabdominal abscess was detected around the anastomosis, the abscess was drained. At the $3^{\text {rd }}$ postoperative day, drains were withdrawn and the patient was discharged. Another patient who had a history of chronic obstructive pulmonary disease underwent laparoscopic right hemicolectomy. He had respiratory distress on the $2^{\text {nd }}$ postoperative day and was followed up in the intensive care unit with noninvasive mechanical ventilation for 3 days. No further complications occurred. We did not have any fatal events in our series.

\section{DISCUSSION}

In this study, we presented our case series of 33 patients who underwent laparoscopic colorectal surgery. Laparoscopic sur- 
Table 3. Histopathologic characteristics of patients with colorectal cancer $(n=30)$

\begin{tabular}{|l|l|}
\hline Grade & Number (\%) \\
\hline 1 & $3(10)$ \\
\hline 2 & $8(60)$ \\
\hline 3 & $1(3)$ \\
\hline Undetermined & $8(27)$ \\
\hline T stage & \\
\hline In situ carcinoma & $2(6)$ \\
\hline 1 & $1(3)$ \\
\hline 2 & $3(10)$ \\
\hline 3 & $14(47)$ \\
\hline 4 & $6(20)$ \\
\hline No tumor & $4(13)$ \\
\hline N stage & \\
\hline 0 & $20(66.6)$ \\
\hline 1 & $7(23.3)$ \\
\hline 2 & $3(10)$ \\
\hline Number of retrieved lymph nodes (median) & $17(4-28)$ \\
\hline Lymphovascular invasion & $10(33)$ \\
\hline Perineural invasion & $8(275)$ \\
\hline Positive surgical margin & $0(0)$ \\
\hline
\end{tabular}

gery constitutes $10 \%$ of our colorectal operations. Therefore, the number of patients is low as compared to open surgery. Major limitations of this study are the small sample size, short follow-up period and the retrospective design of the study. In addition, the outcomes of this study group were not compared with that of patients with open surgery.

Nowadays, laparoscopic surgery is being widely used for the treatment of both malignant and benign colorectal diseases. It has advantages such as better cosmesis, shorter hospital stay, lower incisional hernia incidence and early mobilization as compared to open surgery. Grupta et al. found that systemic immunity appears to be preserved better in laparoscopic surgery as compared to open surgery (10). In our series, laparoscopic colorectal surgery constituted $10 \%$ of all colorectal cases and our rate of conversion to open surgery was $8 \%$. The literature states the conversion rate to open surgery between $17-20 \%$ (11-13). Our low conversion rate may be due to patient selection.

The complication rate in laparoscopic colorectal surgery is not higher than in open surgery (14-16). In previous studies, the complication rates were found to be between 1.5-36\% (1719). Our complication rate was determined as $15 \%$. The most common complication in our series was superficial surgical site infection (6\%).

There are relative contraindications for laparoscopic colorectal surgery such as major cardiac or pulmonary disease, portal hypertension, coagulopathy, pregnancy, tumor obstruction and/ or perforation, as well as T4 tumors (20). In our study, 6 (18\%) patients had T4 disease and underwent laparoscopic resection.

In laparoscopic colorectal surgery, using a video processor with a magnification function aids the surgeon to visualize the hypogastric plexus, ureters and gonadal arteries. Direct visualization helps decreasing the risk of major injuries to these vital structures. Our follow-up period and study size are low to interpret its oncologic outcomes. The minimum number of dissected lymph nodes is reported as 12 for proper staging (21). Our mean number of lymph nodes in the final pathology specimens was 17 , and all the resection specimens had tumorfree surgical margins.

\section{CONCLUSION}

Laparoscopy is currently not the gold standard in colorectal surgery. Nevertheless, it can be performed safely by colorectal surgeons and has advantages such as low complication rate, short hospital stay, sufficient extent of surgical resection and lymph node dissection.

Ethics Committee Approval: Ethics committee approval was obtained for this study from the ethics committee of Marmara University.

Informed Consent: Written informed consent was obtained from patients who participated in this study.

Peer-review: Externally peer-reviewed.

Author Contributions: Concept - W.A.; Design - W.A., A.C., Ö.G.; Supervision - Ö.G., M.Ü.U., S.Y., A.C.; Resources - W.A., S.Y., H.B.; Materials - W.A., S.Y., A.C., Ö.G.; Data Collection and/or Processing - H.B., W.A., M.Ü.U.; Analysis and/or Interpretation - W.A., S.Y., A.C., Ö.G.; Literature Search - W.A., S.Y., H.B.; Writing Manuscript - W.A.; Critical Review - A.C., M.Ü.U., Ö.G.

Acknowledgements: We would like to thank Prof. Dr. Rasim Gençosmanoğlu for revising the manuscript's language and contents.

Conflict of Interest: No conflict of interest was declared by the authors.

Financial Disclosure: The authors declared that this study has received no financial support.

\section{REFERENCES}

1. Hewitt PM, Ip SM, Kwok SP, Somers SS, Li K, Leung KL, et al. Laparoscopic assisted vs. open surgery for colorectal cancer: comparative study of immune effects. Dis Colon Rectum 1998; 41: 901-909. [CrossRef]

2. Rose J, Schneider C, Yildirim C, Geers P, Scheidbach H, Köckerling F. Complications in laparoscopic colorectal surgery: results of a multicentre trial. Tech Coloproctol 2004; 8: 25-28. [CrossRef]

3. Jacobs M, Verdeja JC, Goldstein HS. Minimally invasive colon resection (laparoscopic colectomy). Surg Laparosc Endosc 1991; 1: 144-150.

4. Berends FJ, Kazemier G, Bonjer HJ, Lange JF. Subcutaneous metastases after laparoscopic colectomy. Lancet 1994; 344: 58. [CrossRef]

5. Vukasin $P$, Ortega AE, Greene FL, Steele GD, Simons AJ, Anthone $\mathrm{GJ}$, et al, Wound recurrence following laparoscopic colon cancer resection: results of the American Society of Colon and Rectal Surgeons Laparoscopic Registry. Dis Colon Rectum 1996; 39: 20-23. [CrossRef] 
6. American Society of Colon and Rectal Surgeons (ASCRS); Gastrointestinal and Endoscopic Surgeons (SAGES), Fleshman J, Marcello P, Stamos MJ, Wexner SD. Focus Group on Laparoscopic Colectomy Education as endorsed by the American Society of Colon and Rectal Surgeons (ASCRS) and the Society of American Gastrointestinal and Endoscopic Surgeons (SAGES): guidelines for laparoscopic colectomy course. Surg Endosc 2006; 20: 11621167. [CrossRef]

7. Kalfaoglu M, Hansel H, Cevheroglu C, Gurkut O, Ciner F, Beroval O, et al, A study on laparoscopic colorectal surgery in T.R.N.C. Kolon Rektum Hast Derg 2013; 23: 157-161.

8. Martel G, Boushey RP. Laparoscopic colon surgery: past, present and future. Surg Clin North Am 2006; 86: 867-897. [CrossRef]

9. Kurt A, Tekinel M, Aksoy S, Yanar H. Laparoscopic resection for the colorectal diseases: first 26 cases. C.Ü. Tıp Fakültesi Dergisi 2008; 30: 14-19.

10. Gupta A, Watson DI. Effect of laparoscopy on immune function. Br J Surg 2001; 88: 1296-1306. [CrossRef]

11. Melotti G, Tamborrino E, Lazzaretti MG, Bonilauri S, Mecheri F, Piccoli M. Laparoscopic surgery for colorectal cancer. Semin Surg Oncol 1999; 16: 332-336. [CrossRef]

12. Stocchi L, Nelson H. Laparoscopic colectomy for colon cancer trial update. J Surg Oncol 1998; 68: 255-267. [CrossRef]

13. Hasegawa H, Kabeshima Y, Watanabe M, Yamamoto S, Kitajima M. Randomized controlled trial of laparoscopic versus open colectomy for advanced colorectal cancer. Surg Endosc 2003; 17: 636640. [CrossRef]
14. Stage JG, Shulze S, Moller P, Overgaard H, Andersen M, RebsdorfPedersen VB. Prospective randomized study of laparoscopic versus open resection for adenocarcinoma. Br J Surg 1997; 84: 391396. [CrossRef]

15. Milsom JW, Bohm B, Hammerhofer KA, Fazio V, Steiger E, Elson P. A prospective randomized trial comparing laparoscopic versus conventional techniques in colorectal cancer surgery: a preliminary report. J Am Coll Surg 1998; 187: 46-54. [CrossRef]

16. Morino M, Parini U, Giraudo G, Salval M, Brachet Contul G, Garrone $C$. Laparoscopic total mesorectal exision: a consecutive series of 100 patients. Ann Surg 2003; 237: 335-342. [CrossRef]

17. Clinical Outcomes of Surgical Therapy Study Group. A comparison of laparoscopically assisted and open colectomy for colon cancer. N Engl J Med 2004; 350: 2050-2059.

18. Curet MJ, Putrakul K, Pitcher DE, Jossloff RK, Zucker KA. Laparoscopically assisted colon resection for colon carcinoma: perioperative results and long term outcome. Surg Endosc 2000; 14: 1062-1066. [CrossRef]

19. Pearlstone DB, Mansfield PF, Curley SA, Kumparatana M, Cook P, Feig BW. Laparoscopy in 533 patients with abdominal mailgnancies. Surgery 1999; 125: 67-72. [CrossRef]

20. Ertem M, Baca B. Laparoskopik kolorektal girişimlerde güncel durum. Ulus Cerrahi Derg 2006; 22: 116-119.

21. McDonald JR, Renehan AG, O'Dwyer ST, Haboubi NY. Lymph node harvest in colon and rectal cancer: Current considerations. World J Gastrointest Surg 2012; 4: 9-19. [CrossRef] 